\title{
Mariacristina Pedrazzini, Le Naturisme au théâtre
}

\section{Mario Richter}

\section{(2) OpenEdition}

\section{Journals}

\section{Edizione digitale}

URL: https://journals.openedition.org/studifrancesi/26747

DOI: 10.4000/studifrancesi.26747

ISSN: 2427-5856

\section{Editore}

Rosenberg \& Sellier

\section{Edizione cartacea}

Data di pubblicazione: 1 avril 2007

Paginazione: 209

ISSN: 0039-2944

\section{Notizia bibliografica digitale}

Mario Richter, «Mariacristina Pedrazzini, Le Naturisme au théâtre», Studi Francesi [Online], 151 (LI | I) |

2007, online dal 30 novembre 2015, consultato il 23 novembre 2021. URL: http://

journals.openedition.org/studifrancesi/26747 ; DOI: https://doi.org/10.4000/studifrancesi.26747

Questo documento è stato generato automaticamente il 23 novembre 2021.

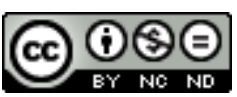

Studi Francesi è distribuita con Licenza Creative Commons Attribuzione - Non commerciale - Non opere derivate 4.0 Internazionale. 


\title{
Mariacristina Pedrazzini, Le Naturisme au théâtre
}

\author{
Mario Richter
}

\section{NOTIZIA}

MARIACRISTINA PEDRAZZINI, Le Naturisme au théâtre, in "L'analisi linguistica e letteraria", 13 (2005), pp. 189-233.

Con una esposizione ordinata e chiara l'A. ripercorre i momenti salienti del programma variamente elaborato, a partire dal 1896, dai maggiori responsabili del Naturismo. Ha successivamente concentrato il suo interesse sulle opere teatrali di Saint-Georges de Bouhélier (La Victoire, La Tragédie du Nouveau Christ, Le Roi sans couronne, La Tragédie royale, Le Carnaval des enfants). Mentre nella Tragédie du Nouveau Christ e nel Roi sans couronne Bouhélier pone al centro dei suoi drammi la modernità e il popolo (mostrandosi in tal modo ancora legato alla sensibilità naturalista), nella Tragédie royale e soprattutto nel Carnaval des enfants la sua osservazione si concentra su individui esemplari e quasi leggendari, sviluppando notevolmente la problematica psicologica. «Le déterminisme, conclude l'A., ne pose que les bases des événements, c'est la fatalité qui l'emporte et mène les protagonistes à la folie ou à la mort». 